\title{
Assessing the efficiency of green roof technology: A case study of Masjid Kota Iskandar, Nusajaya, Johor
}

\author{
Muhamad Hanafi Rahmat ${ }^{1,2 *}$, Muhd Hariz Mohkatar ${ }^{1,2}$, Izudinshah Abd \\ Wahab $^{1,2}$, Nur Nasuha Abd. Salam ${ }^{1,2}$ Hazri Abdul Aziz ${ }^{1,2}$, and Nor Haslinda \\ Abas $^{1,2}$ \\ ${ }^{1}$ Jamilus Research Center, Faculty of Civil and Environmental Engineering, Universiti Tun Hussein \\ Onn Malaysia, 86400, Batu Pahat, Malaysia. \\ ${ }^{2}$ Faculty of Civil and Environmental Engineering, Universiti Tun Hussein Onn Malaysia, 86400, \\ Batu Pahat, Malaysia.
}

\begin{abstract}
Green roof is a system that had been identified as a medium that is able to reduce the thermal temperature of a building. It is an efficient way of reducing heat especially for hot climate countries like Malaysia. This study was conducted to assess the ability and the effectiveness of green roof in controlling the temperature of a building and also to make a comparison of its performance with the conventional roof. The study was conducted at the Masjid Kota Iskandar, Nusajaya, Johor. For this case study, Infrared Thermometer and 4 in 1 Meter Kit were used to record the temperature (maximum and minimum) during the day on the surface of the green roof and conventional roof as well as its relative humidity. The experiments were conducted during sunny days from 8.00 am to $6.00 \mathrm{pm}$ at an interval of two hours on two different dates which were 18th March 2017 and 4th April 2017. Few locations for the data to be collected were plotted on the surface of both roofs and the readings of maximum and minimum surface roof temperatures were recorded for comparison. Based on the research that had been carried out, it can be concluded that the usage of green roof was able to reduce the average surface temperature in the range of $3.6^{\circ} \mathrm{C}-11.1^{\circ} \mathrm{C}$ as compared to the conventional roof. This result had proven that there was a decrease in temperature for the green roof as compared to the conventional roof. It had shown that the usage of the green roof in a building was an efficient way of reducing building temperature and also an effective way to achieve sustainability in architecture and engineering design.
\end{abstract}

\section{Introduction}

Global warming is one of the signs of the ecological imbalance and there was an increase in the global temperature between $0.4^{\circ} \mathrm{C}$ to $0.5^{\circ} \mathrm{C}$ every 5 years starting in 1952 . It is estimated that between 1990 and 2025 global temperatures will be rising between $0.8^{\circ} \mathrm{C}$ up

\footnotetext{
* Corresponding author: mdhanafi@uthm.edu.my
} 
to $3.6^{\circ} \mathrm{C}$ [1]. Global warming occurs due to two main mechanisms which are the greenhouse effect and the depletion of ozone layer. Despite the cause of nature itself, the contribution of human activities seems to be the most fundamental aspects rooting to this issue. Many alternatives to reduce the increase of the environmental temperature had been taken as ways of preventing it from becoming worst and one of the ways is by using the green roof. In the context of Malaysia, it is still not widely being used and not the popular option to be adopted by the Malaysian but it should become a practice as the green roof is able to reduce the temperature of the thermal radiation from the sun. In fact, the green roof helps to meet the aesthetic and landscape needs, and create extra architectural space for the user for them to enjoy their outdoor activities with families at their own personal space [2].

\section{Literature Review}

There are two types of green roof which are the intensive green roof and the extensive green roof. The intensive green roof system is made up of various plants which are the herbaceous plants of small trees with a systematic maintenance and inclusive irrigation system [3]. In addition, it is also can be operated as a garden that provides a space for the public. Intensive green roofs have a depth measuring of $200 \mathrm{~mm}-2000 \mathrm{~mm}$ [4]. Due to its nature, this type of green roof has a large potential for exploration in design and biodiversity. Figure 1 shows the example of a recreational area of an apartment comprises the private garden and public recreational park which had been adopted by using the intensive green roof type. This selection of roof designs required extra maintenance and care. Rooftop farms and vegetables on the roof are the good examples that clearly show that the intensive green roofs require a higher nutrient application and also ongoing maintenance. The excessive burden and extra maintenance are some of the factors of the rising cost for this intensive type of green roof.

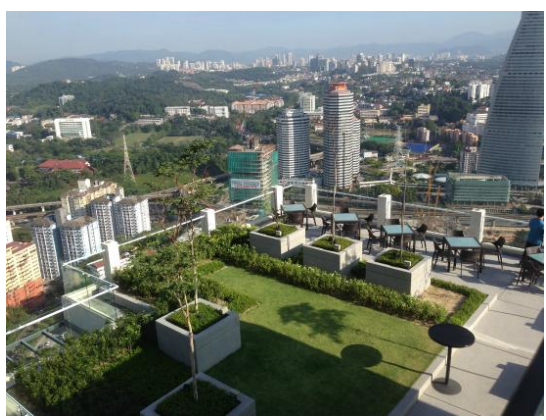

Fig. 1. Intensive green roof. [7]

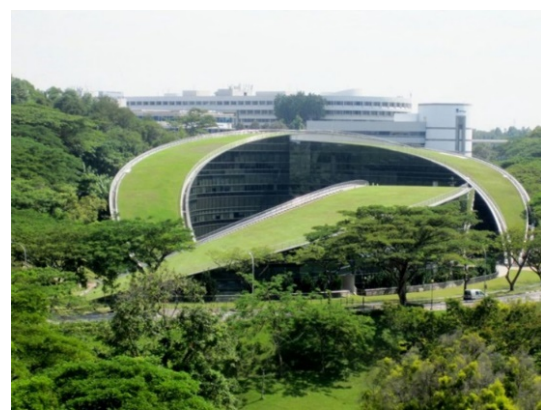

Fig. 2. Extensive green roof. [7]

Contrasting from the previous type of green roof, the extensive green roof is designed with independent plantations which only required minimal maintenance and supervision [5]. It was not usually for recreational purposes, does not require artificial system and in some occasions can be combined with the intensive green roof system. This is because the cultivation of this plant is natural and its main objective is to create a sustainable community plants on the roof [6]. As the protection of the roof, waterproofing membrane will be used to remain watertight in extreme conditions such as constant moisture, alkaline conditions, high and low exposure to plant roots, fungus and bacterial organisms. Figure 2 shows the example of this type of green roof. Another reason of why the extensive green 
roof system is practiced is to enhance the natural visual appearance, reduce the environmental impact of the building, creating a natural habitat for plants and animals and addition to the aesthetic value of the building itself. Extensive green roofs contain plants which are smaller such as bushes, sedums or better known as shrubs in the ground, and herbs. It is self-sustainable except for the annual routine maintenance which happens once a year and requires the cultivation of new fertilizers [7].

Table 1 below shows the difference between the intensive and extensive green roof. For both types, the visual looks of the plants are not very significant to be considered but the main consideration should lie on whether the roof is designed for the recreational purposes area or not. If it is meant for recreation, the intensive green roof is required for this type of cultivation [8]. However, if it is simply to promote a more natural look on the roof, the extensive type should come into consideration. Due to its ability to be used as recreational places, the intensive type of green roof is more likable to be adopted by most of the building owner. It is more interesting and gets attraction from the public. Both types of the green roofs can be adopted on the new and old buildings, but some considerations such as the need to add in additional loads on the roof, design analysis, research and also additional supporting structures for building support, need to be taken into consideration in order to ensure the building's stability and durability throughout its life-span [6].

Table 1. Comparison green roof between intensive and extensive. [4]

\begin{tabular}{|c|c|c|}
\hline GREEN ROOF & INTENSIVE & EXTENSIVE \\
\hline Cost & High & Low \\
\hline Maintenance & High & Low \\
\hline Plant & High & $50 \mathrm{~mm}-150 \mathrm{~mm}$ \\
\hline Depth & $200 \mathrm{~mm}-2000 \mathrm{~mm}$ & $72.6-169.4 \mathrm{~kg} / \mathrm{m}^{2}$ \\
\hline Weight & $290-967.7 \mathrm{~kg} / \mathrm{m}^{2}$ & Low \\
\hline
\end{tabular}

One of the case studies on the green roof in Malaysia had been done by Ahmad et al. [9]. The research was conducted to identify the ability of the green roof to provide positive impacts on the ecosystem such as reduction in temperature and the ability to improvise the quality of the environmental landscape such as in Figure 3.
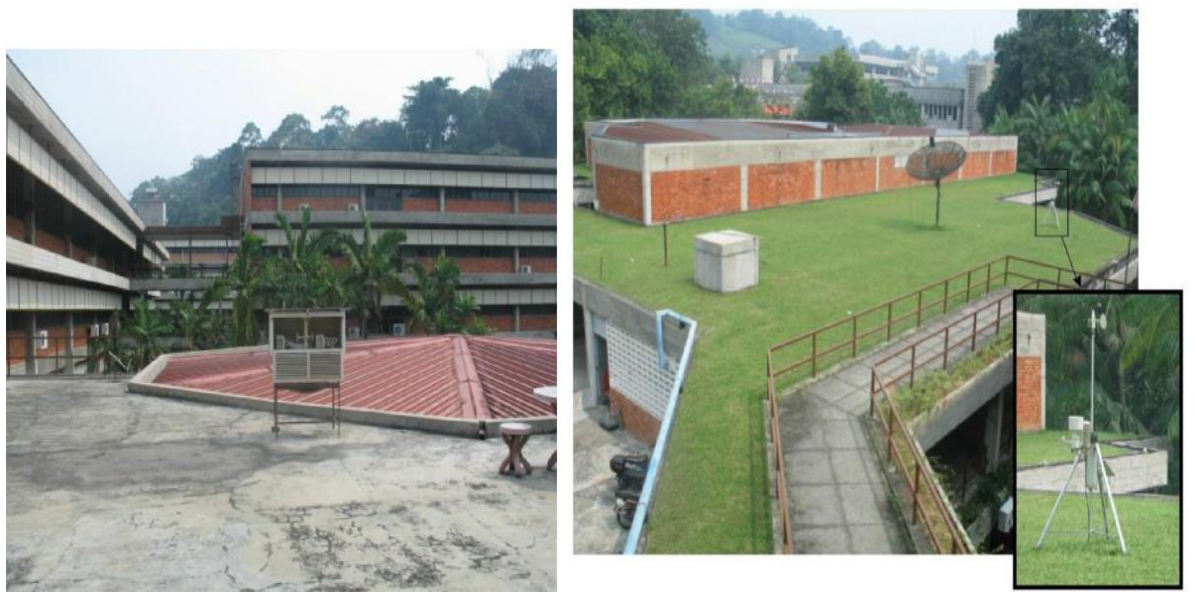
Fig. 3. Concrete roof (left) and green roof (right) at UKM, Bangi. [9]

For this research, the ambient temperatures in October 2016 of the plots marked at the chosen sites (for concrete and green roof) were measured using Infrared Thermometer. Based on the daily changes, the concrete roof had constantly recorded high temperature in average ranging from $26.85^{\circ} \mathrm{C}$ to $41.35^{\circ} \mathrm{C}$ as compared to the green roof, especially in the afternoon. However, the results recorded at the green roof had shown a more stable temperature in average throughout the day ranging from $24.83^{\circ} \mathrm{C}$ to $29.76^{\circ} \mathrm{C}$

This study was able to validate the use of vegetation to cover the roof as an effective way of cooling down the surface temperature. From the results, the green roof had shown better temperature as the transpiration rate of evaporation process was high at the green roof area. However, more latent heat energy was produced at the concrete roof due to the lack of evaporation process. This was finally had increased the overall heat flux and thus increasing the ambient temperature.

Besides that, another case study had been conducted Blanusa et al. [10] to demonstrate that a cooling effect by the plants would be able to reduce the surface heat of the green roof. This was due to the transpiration of water through stomata and direct shading. The experiment had been conducted using Stachys which had the lowest surface temperature even with limited soil moisture and closing stomata. A comparison was done between Stachys's leaves and Stachys's leaves with hairs trimmed. The result had shown that hairs on the leaves of Stachys reduced the amount of infra-red radiation from leaf, thus making the leaves cooler.

Another comparison was done by Schrader and Boning [11] on the selected abiotic properties and collembolan densities between five old extensive green roofs and five young extensive green roofs. Collembolans are typical pioneer microarthropods and transported by air during the primary succession, the pioneer period [12]. Schrader and Boning [11] found that acidification and increasing contents of organic carbon took place in old green roofs which directly was able to improve the soil condition and promote urban biodiversity. Besides that, soil is another important factor to decrease the roof temperature as it holds water and heat [14] [13].

\section{Materials and Methods}

For this case study review, experiments were carried out on two different roof surface conditions which were the green roof (entensive green roof) and the conventional roof at Masjid Kota Iskandar, Nusajaya, Johor. The developer, Cahaya Jauhar Sdn. Bhd., had mentioned that Matrella Zoysia grass species had been planted on the green roof whereas Eurotiles Florana had been used as the roof tiles. The main objective of this study was to determine the ability of the green roof to control the surface temperature of the chosen site (Figure 4 and Figure 6). Infrared Thermometer and 4 In 1 Meter Kit were used to record the temperature readings on the plots that had been marked (on the green roof and conventional roof) as what had been shown in Figure 5. Two readings (maximum and minimum) were recorded at the indicated area at an interval of two hours for ten hours starting from $8.00 \mathrm{am}$ to $6.00 \mathrm{pm}$. On top of that, the 4 in 1 Meter Kit was also able to record the external temperature readings (exposed), room temperature, relative humidity (RH), wind speed and all of these data were recorded for comparison purposes later. 


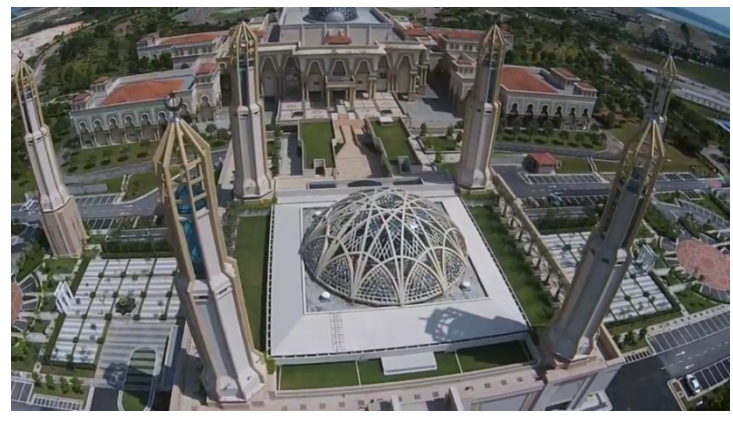

Fig. 4. Top view showing the green roof at Masjid Kota Iskandar, Nusajaya, Johor.
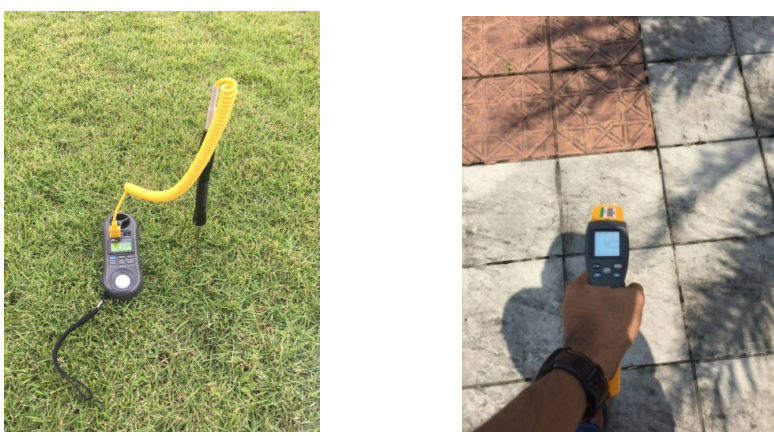

Fig. 5. Method of retrieving data: 4in 1 Meter Kit (left) and Infrared Thermometer (right).

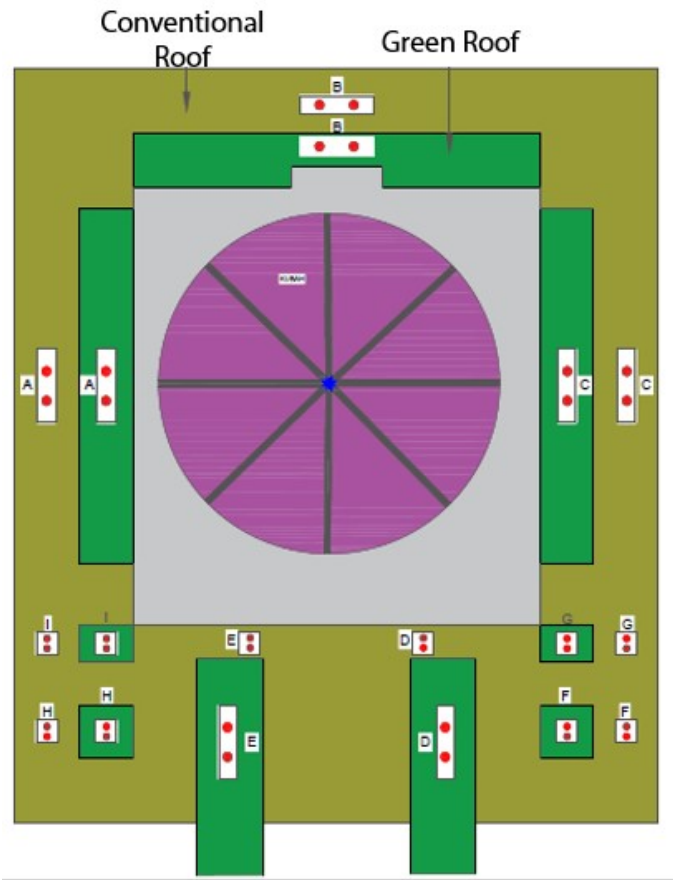

Fig. 6. Surface Marking Plots at Kota Iskandar Mosque, Nusajaya, Johor. 


\section{Results and discussions}

\subsection{Relative Humidity}

Figure 8 shows the graph on the relative humidity for both dates 18th March 2017 and 4th April 2017 at the Masjid Kota Iskandar. High relative humidity would also affect the temperature of the surrounding environment (outdoor temperature) and the room temperature. Form the graph, high humidity had been recorded in the morning and late afternoon while in the afternoon, low values had been recorded for both dates. The higher the humidity, the lower the temperature of the outdoor areas. Therefore, it is important to maintain a high humidity in the outdoor area as it would help to reduce the surface temperature. One of the ways is by having the green roof as by having more vegetation and plantations on the surface, it produces more vaporization activities which indirectly cooling the air and resulting in high humidity and finally, toning down the surrounding temperature.

\section{Relative Humidity (RH) vs Time}

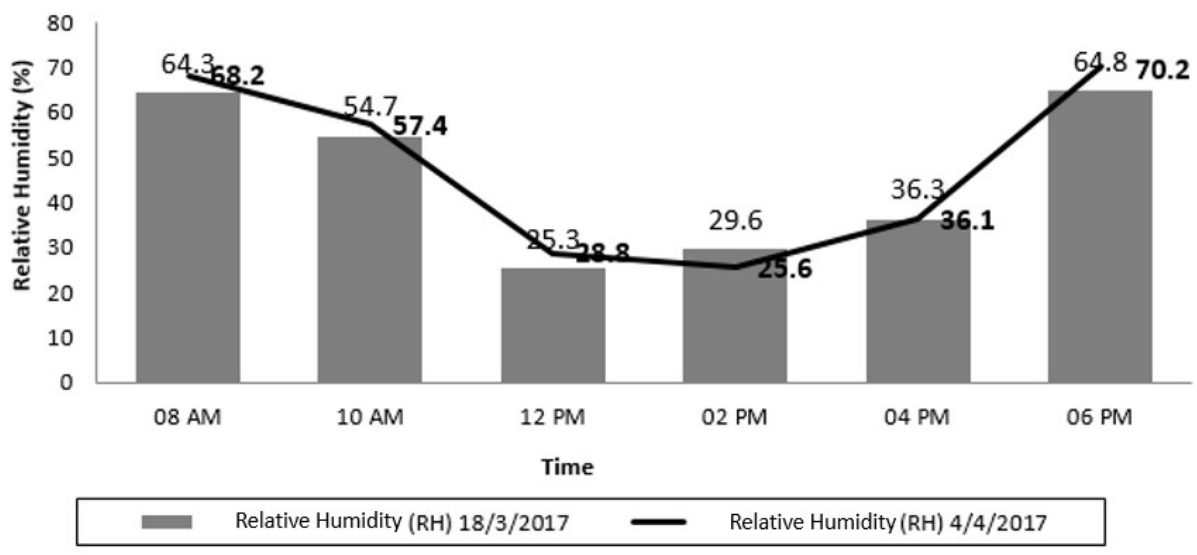

Fig. 8. Comparison Between Relative Humidity (RH) On Different Date Versus Time.

\subsection{Outdoor temperature vs Indoor temperature}

Figure 9 shows the comparison between the outdoor temperature and the room temperature on the date 18th March 2017 at the location chosen. The data was collected on a fine and sunny day. In the period between 8:00 am to 12:00 noon, a sudden increased in temperature's reading was recorded. The green roofs and the conventional roof surfaces reached the highest reading at 12.00 noon. By the late afternoon, the outdoor temperature readings started to decrease continuously. 
Comparison Between Temperature (Exposed) \& Room Temperature (18/3/2017)

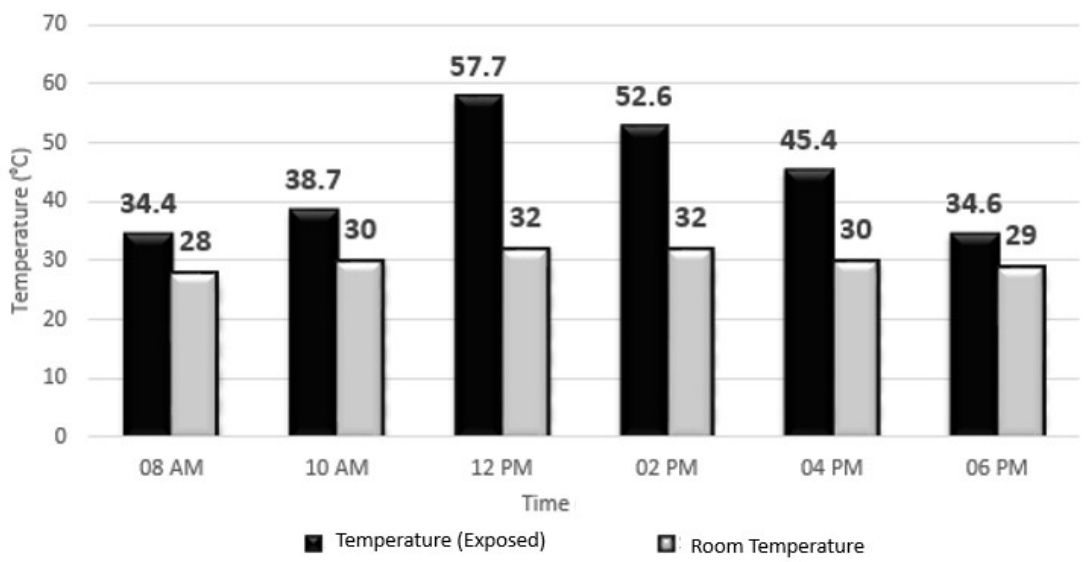

Fig. 9. Comparison Temperature (exposed) \& Room Temperature Versus Time (18/3/2017).

The same pattern had been shown in Figure 10 when comparing the outdoor temperature and the room temperature on the date 4th April 2017 at Masjid Kota Iskandar, Nusajaya, Johor. The maximum outdoor temperature was recorded at $2.00 \mathrm{pm}$ for both room and outdoor temperatures with $57.5^{\circ} \mathrm{C}$ and $34^{\circ} \mathrm{C}$ respectively. After that period, the temperature in both areas started to decrease until late afternoon. The high temperature recorded would result in the high roof surface temperature and this will be affecting the human thermal comfort due to high latent heat absorbed by the roof.

\section{Comparison Between Temperature (Exposed) \& Room Temperature (4/4/2017)}

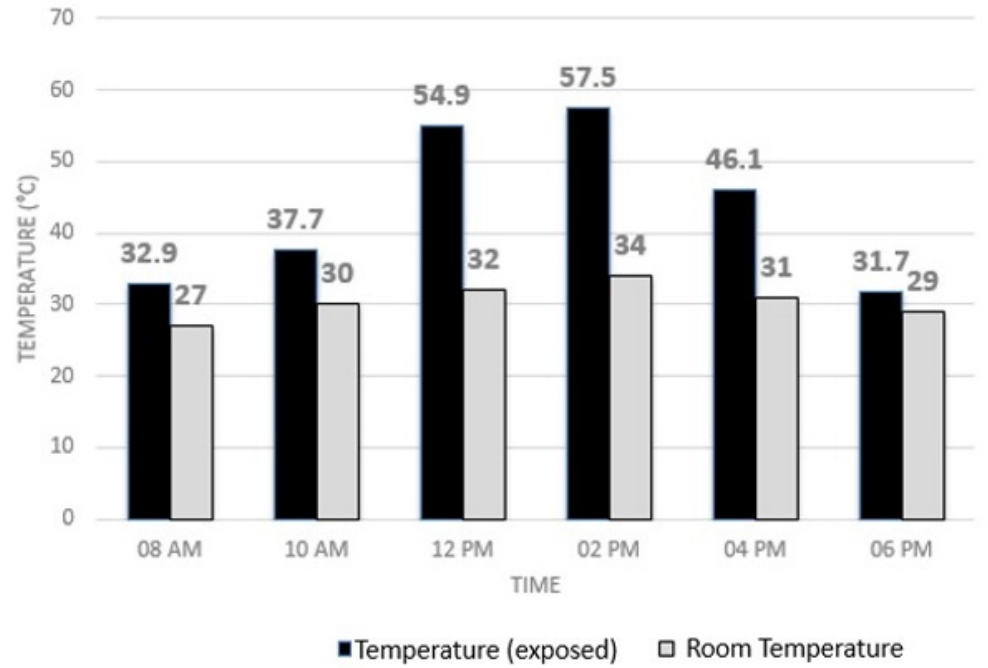

Fig. 10. Comparison Temperature (exposed) \& Room Temperature Versus Time (4/4/2017). 


\subsection{Green Roof vs Conventional Roof}

The graph in Figure 11 shows the temperature readings of the green roof and the conventional roof on the date 18th March 2017. The result for the conventional roof had been recorded in the range between $32.2^{\circ} \mathrm{C}-44.8^{\circ} \mathrm{C}$ and meanwhile for the green roof, the range was between $28.6^{\circ} \mathrm{C}-33.7^{\circ} \mathrm{C}$. The temperatures recorded at the conventional roof had been progressively higher with a drastic change in the afternoon. This was because, the heat from the sun was directly reflected to the surface of the roof and it was recorded the highest in the afternoon as that was the peak hour where the temperature was recorded as the maximum. In contrast to that, the green roof had shown more uniform results with minimal changes from minimum to maximum temperatures recorded. The heat from the sun had been absorbed by the green roof and its components especially Matrella Zoysia grass and the soil where it was able to hold water and heat at the same time. This result had approved that the conventional roof surface was subjected to high temperatures especially in the afternoon as compared to the green roof.

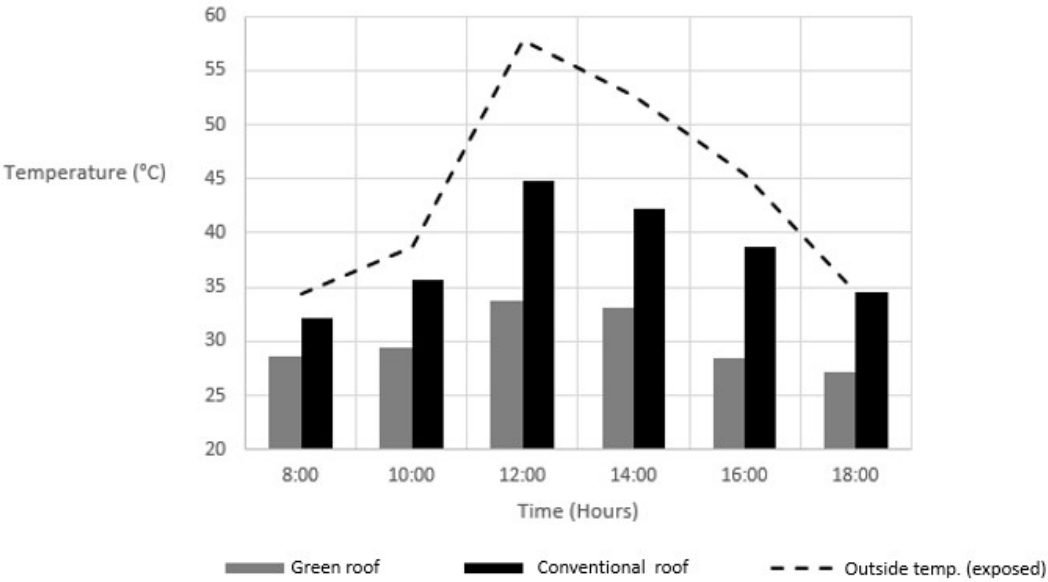

Fig. 11. Comparison Temperature (exposed) versus Time (18/3/2017).

In Figure 12, the same pattern had been recorded. The graph of the temperature readings of the green roof and the conventional roof on the date 4th April 2017 were collected. The data was taken during a sunny day. The flow of the data recorded had indicated no significant difference in temperatures during early in the morning and both roof surfaces had been recording low temperatures. The changes in temperature started to rise steadily as the outdoor exposure gets warmer especially in the afternoon. The average temperature range between $32.5^{\circ} \mathrm{C}-42.1^{\circ} \mathrm{C}$ for the conventional roof and the green roof had an average 
at the range between $26.9^{\circ} \mathrm{C}-32.0^{\circ} \mathrm{C}$. In both cases, it reached the maximum temperature in between 12:00 pm to 2:00 pm. The trend continued to decrease in the late afternoon (after $2.00 \mathrm{pm}$ onwards). On this date, the green roof had shown a more uniform and lower temperatures recorded as compared to the conventional roof. This is again had approved that in comparison between the green roof and the conventional roof, the heat from the sun was not directly being absorbed by the surface of the roof. The grass and the soil on the green roof had been successfully becoming the agents to reduce the thermal heat on the roof.

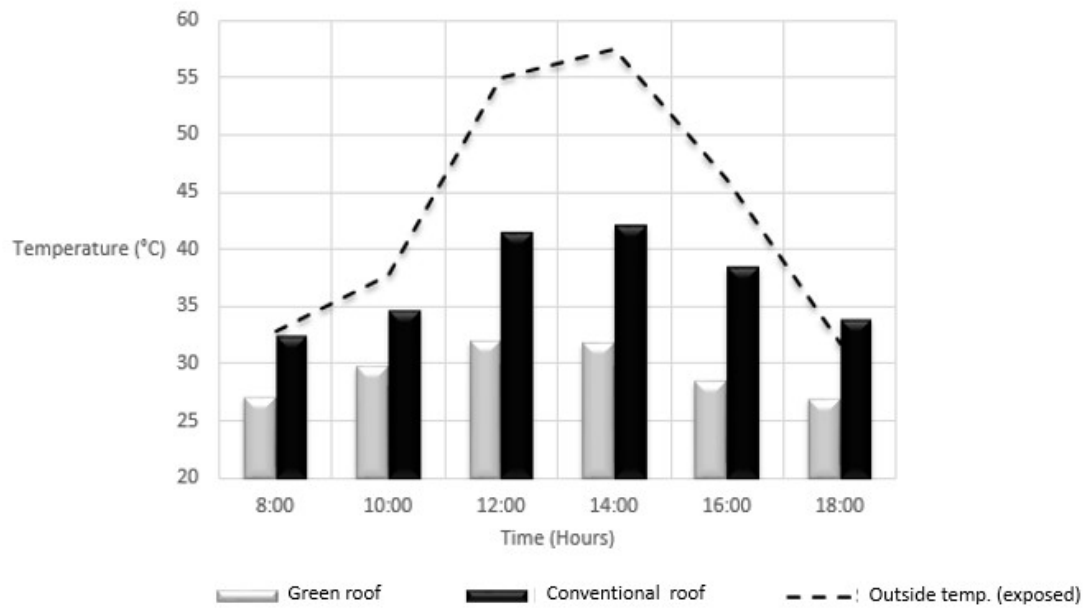

Fig. 12. Comparison Temperature versus Time (18/3/2017).

\section{Conclusion}

As the conclusion, the case study review had been able to clarify and validate the efficiency of having green roof system at the Masjid Kota Iskandar, Nusajaya, Johor. All the experiments had been successfully conducted and the results had been positively supporting the usage of the green roof in a building especially in the country like Malaysia, which is having hot and humid climate throughout the year. The study was conducted directly on the 
green roof and the conventional roof on the chosen site. The data was taken during a fine and sunny day on both dates 18th March 2017 and 4th April 2017 from 8.00am to $6.00 \mathrm{pm}$ for every 2 hours interval. As the result, for both types of the roofs, the pattern of the graph was the same with low temperature recorded in the morning, rose drastically in the afternoon and decreased back in the late afternoon. However, there was a large gap when comparing both temperatures recorded for both types of the roofs at each interval of time recorded. The average surface temperature differences for the green roof and the conventional roof on the date 18 th March 2017 was between the range $3.6^{\circ} \mathrm{C}$ and $11.1^{\circ} \mathrm{C}$ while on the date 4th April 2017, the range was between $4.9^{\circ} \mathrm{C}$ and $10.2^{\circ} \mathrm{C}$. For both dates, the green roof had recorded lower surface temperatures. This result indicated that green roof was able to reduce the heat absorption into the building. Besides that, the green roof also had recorded low temperatures during peak hours of the day (12.00pm to $2.00 \mathrm{pm})$ as compared to the conventional roof. The temperature recorded was below $35^{\circ} \mathrm{C}$ while for conventional roof surface, it was reaching up to $45^{\circ} \mathrm{C}$. On top of becoming an efficient additional element towards sustainability architecture and engineering, the effect of this heat reduction can actually increase life expectancy and reduce the conservation cost of the roof. In addition, the green roof system is also capable in providing an environment which will be more conducive to the public and promotes better life to the human. Therefore, by having the green roof system adopted at the Masjid Kota Iskandar, Nusajaya, Johor was indeed a good decision due to its efficiency in lowering down the roof surface temperature and other benefits mentioned earlier.

The authors are thankful for the financial and technical support provided by the Universiti Tun Hussein Onn Malaysia (UTHM), the Registrar Office of UTHM for supporting this research. Special thanks also dedicated to the management of Masjid Kota Iskandar, Nusajaya, Johor which had been willing to share all the required information and letting us doing our research on the site. On top of that, many thanks also to Cahaya Jauhar Sdn. Bhd., the developer of the mosque for sharing all the required documentations of the mosque.

\section{References}

1. I.H.T. Abdullah, Teknologi Hijau Tingkat Kualiti Hidup, Pacu Ekonomi Negara, Berita Harian, (2015).

2. M.H. Md. Zahir, S.N. Raman, M.F. Mohamed, M. Jamiland \& Z.M. Nopiah, The Perception of Malaysian Architects towards the Implementation of Green Roofs: A Review of Practices, Methodologies and Future Research, E3S Web of Conferences, 3, (2014).

3. L.S. Velazquez, Organic Greenroof Architecture: Sustainable Design for the New Millennium, Environmental Quality Management, 14 (4), (2005).

4. S. Dinsdale, B. Pearen, \& C. Wilson, Feasibility Study for Green Roof Application on Queen's University Campus, (2006).

5. K. L. Getter \& D. B. Rowe, The Role of Extensive Green Roofs in Sustainable Development, HortScience, 41(5), 1276-1285. (2006).

6. W.C. Li \& K.K.A.Yeung, A Comprehensive Study Of Green Roof Performance From Environmental Perspective, International Journal of Sustainable Built Environment, 3(1), 127-134, (2014).

7. R. Maru, Urban Heat Island dan Upaya Penanganannya, Prosiding Seminar Nasional Mikrobiologi Kesehatan dan Lingkungan 2015, 84-94, (2015).

8. R. Mohammed Ahmed \& H. Z. Alibaba, An Evaluation Of Green Roofing In Buildings, International Journal of Scientific and Research Publications, 6(1), 366373, (2016) 
9. S. Ahmad, N. Md. Hashim, \& Y. Mohd Jani, Fenomena Pulau Haba Bandar dan isu alam sekitar di Bandaraya Kuala Lumpur (The Urban Heat Island Phenomena and the Evironmental Issues of Kuala Lumpur City), Geografia : Malaysian Journal of Society and Space, 3(3), 57-67, (2009)

10. T. Blanusa,, M.M. Vaz Monteiro,F. Fantozzi, E. Vysini, Y. Li, R.W. Cameron, Alternatives To Sedum On Green Roofs: Can Broad Leaf Perennial Plants Offer Better 'Cooling Service'?, Building and Environment, 59, 99-106, (2003)

11. S. Schrader, M. Boning, Soil Formation On Green Roofs And Its Contribution To Urban Biodiversity With Emphasis On Collembolans. Pedobiologia 50, 347-356 (2006)

12. W. Dunger, The Return Of The Soil Fauna To Coal Mined Areas In The German Democratic Republic, pp. 307-337 (1989)

13. J.S. Maclvor, J. Lundholm, Performance Evaluation Of Native Plants Suited To Extensive Green Roof Conditions In A Maritime Climate, Ecological Engineering, 37, 407-417 (2011)

14. K.L. Getter, D.B. Rowe, B.M. Cregg, Solar Radiation Intensity Influences Extensive Green Roof Plant Communities, Urban Forestry and Urban Greening, 8 (4), 269-281 (2009) 